\title{
DIREITOS FUNDAMENTAIS TRABALHISTAS: PERSPECTIVAS TEÓRICAS NO BRASIL E NA ALEMANHA
}

\author{
Camila Miranda de Moraes* \\ Adalberto Martins**
}

SUMÁRIO: Introdução; 2 Eficácia e aplicabilidade das normas definidoras de direitos fundamentais; 3 Validade, vigência e eficácia da norma jurídica; 40 problema da eficácia das normas definidoras de direitos sociais trabalbistas; 5 Considerações finais; Referências.

RESUMO: Opresenteartigobuscaanalisar aspectos dateoriados direitosfundamentais em torno das normas constitucionais definidoras de direitos trabalhistas no Brasil e na Alemanha. Para isso far-se-á um breve estudo dos conceitos de validade, vigência e eficácia da norma jurídica. A força normativa da Constituição deriva não apenas das normas jurídicas nela inscritas, mas da possibilidade de exercício e fruição do quanto contido nessas normas. Pretende-se enfocar o problema da eficácia dos direitos fundamentais sob as perspectivas da doutrina alemã por meio dos autores Andreas Joachim Krell, Ernst Forsthoff e Ernst-Wolfgang Böckenförde. Forsthoff e Böckenförde defendem que os direitos fundamentais não têm aplicabilidade imediata e que há de se analisar as hipóteses de aplicação dos direitos fundamentais caso a caso, pois para serem aplicados os direitos fundamentais necessitariam de graduação e diferenciação para cada caso particular. A teoria da reserva do possível foi adotada na Alemanha em julgamento do Supremo Tribunal da República Federal da Alemanha que reconheceu um problema de estrutura dos direitos fundamentais sociais e delimitou o gozo dos direitos fundamentais sociais na medida em que fosse possível ao Estado garantir, em seu orçamento, a verba necessária para sua fruição e custeio. Tal teoria não pode ser adotada indiscriminadamente no Brasil, pois, conforme expõe Andreas Joachim Krell, a doutrina portuguesa utilizou-se das teorias do direito alemão, e muitos doutrinadores brasileiros simplesmente transpuseram estas teorias (como reserva do possível e mínimo existencial) para o direito brasileiro. Krell condena tal prática dizendo que não condiz com os verdadeiros preceitos do direito comparado e demonstra que a decisão do tribunal alemão não poderia simplesmente ser transposta para o Brasil, seja por se tratar de um país de realidade completamente distinta da Alemanha, ou por causa das diferenças nos sistemas jurídicos dos dois países, seja por causa da flagrante incompatibilidade na aplicação da tese no Brasil.

PALAVRAS-CHAVE: Efetividade; Aplicabilidade; Direitos trabalhistas.

\footnotetext{
Doutoranda em Direito do Trabalho (PUC-SP); Juíza do Trabalho Substituta (TRT $7^{\mathrm{a}}$ região), Brasil.

** Docente Doutor da Faculdade de Direito da PUC/SP (graduação, mestrado e doutorado), Desembargador do Tribunal Regional do Trabalho da $2^{\mathrm{a}}$ região; Diretor da Escola Judicial do TRT-2 ${ }^{\mathrm{a}}$ região no biênio 2016-2018, Brasil.
} 


\title{
BASIC LABOR RIGHTS: THEORETICAL PERSPECTIVES IN BRAZIL AND GERMANY
}

\begin{abstract}
Current paper deals with the theory of basic rights on constitutional norms in labor rights in Brazil and Germany. A brief analysis of validity, duration and efficiency of the juridical norm is provided. The Constitution's normative strength is not merely derived from juridical norms but also from the possibility of exercise and fruition of what lies in these norms. The efficaciousness of basic rights is focused from the perspective of German ideology proposed by Andreas Joachim Krell, Ernst Forsthoff and Ernst-Wolfgang Böckenförde. Forsthoff and Böckenförde state that basic rights do not have immediate applicability and one should analyze the hypothesis of applying basic rights case by case. This is due to the fact that fundamental rights would require graduation and differentiation for each individual case. The Theory of Possible Reserve was employed in Germany at the High Court of the Federal Republic of Germany which acknowledged problems in the structure of social basic rights and limited the fruition of social basic rights according to the possibility that the State can guarantee the required budget for their costs and fruition. The above theory may not be employed in Brazil since, according to Andreas Joachim Krell, Portuguese doctrine used the German theories of rights and several Brazilian lawyers merely transposed these theories (as possible reserve and existential minimum) to Brazilian law. Krell condemns this practice since it fails to comply with the true precepts of comparative law. He shows that the decision of the German courts may not be simply transposed to Brazil due to the latter being totally different from Germany and due to the differences in the judicial system of both countries. There is a flagrant incompatibility in the application of the thesis in Brazilian courts.
\end{abstract}

KEY WORDS: Effectiveness; Applicability; Labor rights.

\section{DERECHOS FUNDAMENTALES LABORALES: PERSPECTIVAS TEÓRICAS EN BRASIL Y EN ALEMANIA}

RESUMEN: En el presente artículo se busca analizar aspectos de la teoría de los derechos fundamentales en torno de las normas constitucionales definidoras de derechos laborales en Brasil y en Alemania. Para eso se hará breve estudio de los conceptos de validad, vigencia y eficacia de la norma jurídica. La fuerza normativa de la Constitución deriva no sólo de las normas jurídicas en ella inscritas, sino de la posibilidad de ejercicio y disfrute del contenido de esas normas. Se pretende enfocar el problema de la eficacia de los derechos fundamentales bajo las perspectivas de la doctrina alemana por intermedio de los autores Andreas Joachim Krell, Ernst 
Forsthoff y Ernst-Wolfgang Böckenförde. Forsthoff y Böckenförde defienden que los derechos fundamentales no tienen aplicabilidad inmediata y que hay que analizarse las hipótesis de aplicación de los derechos fundamentales uno a uno pues para ser aplicados, los derechos fundamentales necesitarían de gradación y diferenciación para cada caso en particular. La teoría de la reserva del posible fue adoptada en Alemania en juzgamiento del Supremo Tribunal de la República Federal de Alemania que reconoció un problema de estructura de los derechos fundamentales sociales y delimitó el gozo de los derechos fundamentales sociales en la medida en que fuera posible al Estado garantizar, en su presupuesto, los fondos necesarios para su disfrute y costeo. Tal teoría no puede ser adoptada indiscriminadamente en Brasil pues conforme expone Andreas Joachim Krell, la doctrina portuguesa se utilizó de las teorías del derecho alemán y muchos doctrinadores brasileños simplemente transpusieron estas teorías (como reserva del posible y mínimo existencial) al derecho brasileño. Krell condena tal práctica, diciendo que no concuerda con los verdaderos preceptos del derecho comparado, y demuestra que la decisión del tribunal alemán no podría simplemente ser trasladada a Brasil, sea por tratarse de un país de realidad completamente distinta de la de Alemania, o a causa de las diferencias en los sistemas jurídicos de los dos países, sea a causa de la flagrante incompatibilidad en la aplicación de la tesis en Brasil.

PALABRAS CLAVE: Efectividad; Aplicabilidad; Derechos laborales.

\section{INTRODUÇÃO}

A permanente evolução e modificação das relações de trabalho e dos meios de produção no mundo é uma realidade. A cada dia nos deparamos com novas tecnologias, muitas delas impulsionadoras de novos negócios e formas de trabalho. Entretanto, o problema da eficácia e efetividade das normas jurídicas definidoras de direitos sociais continua a existir e ser um tema controvertido.

$\mathrm{O}$ ordenamento jurídico brasileiro possui um vasto arcabouço de normas jurídicas protetoras dos direitos sociais laborais no âmbito constitucional e infraconstitucional.

No plano constitucional há de se observar que os valores sociais do trabalho, da livre iniciativa e da dignidade da pessoa humana estão inscritos como fundamentos da República Federativa do Brasil (art.1 $\left.{ }^{\circ}, \mathrm{CF}\right)$ e que o trabalho está inserido entre os direitos sociais (art.6 $\left.6^{\circ}, \mathrm{CF}\right)$. 
Por sua vez, o artigo $7^{\circ}$ da Constituição Federal, nos seus 34 incisos, traz uma lista meramente exemplificativa dos direitos dos trabalhadores urbanos e rurais, o que significa dizer que há permissão para criação ou adoção de outros desde que visem à melhoria da condição social dos trabalhadores - conclusão extraída da parte final do "caput" do mesmo dispositivo constitucional.

Além disso, é importante mencionar que o artigo $7^{\circ}$ da Constituição está inserido no capítulo II ("Dos direitos sociais"), que por sua vez encontra-se dentro do título II ("Dos direitos e garantias fundamentais"). Em razão disso, e do disposto no parágrafo primeiro do artigo $5^{\circ}$ desta mesma Constituição, boa parte da doutrina brasileira defende que os direitos sociais dos trabalhadores têm aplicação imediata e ostentam a condição de cláusulas pétreas.

O presente artigo busca analisar o problema da eficácia e da aplicabilidade das normas definidoras de direitos sociais laborais no Brasil e dar um enfoque ao tema sob as perspectivas da doutrina alemã por meio dos autores Andreas Joachim Krell, Ernst Forsthoff e Ernst-Wolfgang Böckenförde.

Quanto aos aspectos metodológicos, as hipóteses apresentadas foram investigadas mediante pesquisa bibliográfica, em que são analisadas algumas obras que tratam do assunto, e pesquisa documental, pois exploramos diversos diplomas normativos existentes atinentes aos tópicos discutidos. A tipologia da pesquisa, segundo a utilização dos resultados, é pura. Segundo a abordagem, a tipologia da pesquisa é qualitativa, visto que busca desenvolver a problemática com base numa pesquisa subjetiva, ou seja, preocupando-se com o aprofundamento e abrangência da compreensão das ações e relações humanas. Quanto aos objetivos, a pesquisa é descritiva e exploratória, uma vez que procura aperfeiçoar as sugestões e ajudará na formulação de hipóteses para pesquisas posteriores.

\section{EFICÁCIA E APLICABILIDADE DAS NORMAS DEFINIDORAS DE DIREITOS FUNDAMENTAIS}

Embora a discussão em torno da teoria dos direitos fundamentais, seu surgimento histórico, características, conceitos, alcance e dimensões tenha grande importância, tema de relevância ainda maior concerne ao problema de sua eficácia e aplicabilidade. Afinal, a teoria constitucional brasileira classifica os direitos sociais como direitos fundamentais, e estes têm aplicação imediata, conforme disciplina a Constituição de 1988 , em seu artigo $5^{\circ}$, parágrafo primeiro. 
Antes de tratar dos problemas ligados à eficácia das normas constitucionais relacionadas a direitos trabalhistas, importa observar que a doutrina já registra que o principal catálogo de legislação infraconstitucional sobre o tema não é respeitado ou cumprido desde sua publicação.

Se fosse para a CLT ter uma força real, seria de esperar que seu impacto no mundo do trabalho fosse mais claramente sentido no núcleo Brasil industrial moderno. [...] o abismo entre aparência e realidade era tão grande que parecia intransponível. Direitos garantidos categoricamente em lei eram rotineiramente desrespeitados na prática daqueles que gerenciavam a expansão do setor industrial. ${ }^{03}$

Para José Afonso da Silva "[...] as normas constitucionais que enunciam os direitos individuais são de aplicabilidade imediata e direta. ${ }^{{ }^{04}}$ Andréas Joachim Krell também adere ao entendimento de que as normas sobre direitos fundamentais são de aplicação imediata conforme disposto no parágrafo $1^{\circ}$ do artigo $5^{\circ}$ da Constituição de 1988 e diz que há regulamentações semelhantes às da Constituição de 1988 nas Cartas de Portugal e da Alemanha. Para este autor, "esse dispositivo serve para salientar o caráter preceptivo e não programático dessas normas, deixando claro que os Direitos Fundamentais podem ser imediatamente invocados, ainda que haja falta ou insuficiência da lei." ${ }^{05}$

O grande problema, portanto, não é delimitar quais são os direitos que a Constituição confere aos trabalhadores, mas como possibilitar sua fruição. Norberto Bobbio já chamava a atenção para tal fato asseverando "que o problema grave de nosso tempo, com relação aos direitos do homem, não era mais o de fundamentálos, e sim o de protegê-los." ${ }^{\text {06 }}$

Norberto Bobbio acentua a dificuldade de realização prática dos direitos fundamentais, em particular dos direitos sociais, tendo em vista o desnivelamento ou diferença de status que existe entre as gerações de direitos ${ }^{07}$. Segundo esse autor

\footnotetext{
${ }^{03}$ FRENCH, John D. Afogados em leis: a CLT e a cultura política dos trabalhadores brasileiros. São Paulo: Perseu Abramo, 2001, p.15-16.

${ }^{04}$ SILVA, José Afonso da. Aplicabilidade das normas constitucionais. 6. ed. São Paulo: Malheiros, 2003, p.140.

${ }^{05}$ KRELL, Andreas Joachim. Direitos sociais e controle judicial no Brasil e na Alemanha: os (dês) caminhos de um direito constitucional "comparado" Porto Alegre: Sergio Antonio Fabris, 2002, p.37-38.

${ }^{06}$ BOBBIO, Norberto. A era dos direitos. 8. ed. Rio de Janeiro: Campus, 1992, p.25.

${ }^{07}$ A doutrina constitucional majoritária faz a divisão ou classificação dos direitos fundamentais através de "gerações" ou dimensões. Assim, existiriam três gerações de direitos fundamentais. A primeira geração trata dos direitos de liberdade; a segunda, dos direitos de igualdade (onde incluem-se os direitos sociais); a terceira, dos direitos de fraternidade. Vide BONAVIDES, Paulo. Curso de Direito Constitucional. 14. ed. São Paulo: Malheiros, 2004, p.563-564.
} 
O campo dos direitos do homem - ou, mais precisamente, das normas que declaram, reconhecem, definem, atribuem direitos ao homem - aparece, certamente, como aquele onde é maior a defasagem entre a posição da norma e sua efetiva aplicação. E essa defasagem é ainda mais intensa precisamente no campo dos direitos sociais. Tanto é assim que na Constituição italiana, as normas que se referem a direitos sociais foram chamadas pudicamente de 'programáticas'. Será que já nos perguntamos alguma vez que gênero de normas são essas que não ordenam, proíbem ou permitem bic et nunc, mas ordenam, proíbem e permitem num futuro indefinido e sem um prazo de carência claramente delimitado? E, sobretudo, já nos perguntamos alguma vez que gênero de direitos são esses que tais normas definem? Um direito cujo reconhecimento e cuja efetiva proteção são adiados sine die, além de confiados à vontade de sujeitos cuja obrigação de executar o 'programa' é apenas uma obrigação moral ou, no máximo, política, pode ainda ser chamado corretamente de 'direito'?08 (grifos nossos)

O problema da aplicabilidade dos direitos sociais é visualizado por José Afonso da Silva por um ângulo diferente do de Norberto Bobbio. Para Silva, o problema que se coloca na doutrina consiste em "buscar mecanismos constitucionais e fundamentos teóricos para superar o caráter abstrato e incompleto das normas definidoras de direitos sociais, ainda concebidas como programáticas, a fim de possibilitar sua concretização prática." ${ }^{09}$

Para este autor "[...] o reconhecimento dos direitos sociais, como instrumentos de tutela dos menos favorecidos, não tem tido a eficácia necessária para reequilibrar a posição de inferioridade que lhes impede o efetivo exercício das liberdades garantidas." 10

\section{VALIDADE, VIGÊNCIA E EFICÁCIA DA NORMA JURÍDICA}

Os estudos da teoria geral do direito fazem diferenciação entre os conceitos de validade, vigência e eficácia das normas constitucionais. Faremos aqui uma breve distinção, com vistas à manutenção do rigor terminológico e para melhor elucidação do tema.

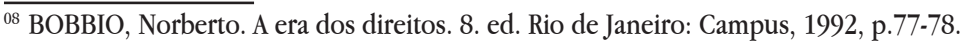

${ }^{09}$ SILVA, José Afonso da, op. cit., 2003, p.140.

${ }^{10}$ Idem, p.141.
} 
A validade de determinada norma jurídica pode ser abordada por dois prismas. Por um, significa que a norma foi elaborada pelo órgão competente para tal ou de acordo com os procedimentos exigidos para sua validade. Por outro, quer dizer que a norma obedece aos ditames da Constituição, estando de acordo com ela.

Assim, norma formalmente válida seria aquela que é oriunda de ato legítimo de autoridade, conforme o trâmite legalmente estabelecido em norma que lhe é superior e que não foi revogada. Mesmo que não tenha sido aplicada, ou que esteja sendo descumprida, a norma poderá ser considerada válida. ${ }^{11}$

A vigência da norma jurídica é um conceito distinto de validade. A norma vigente é dotada de validade e está apta a entrar no mundo jurídico e surtir efeitos. Isso, entretanto, não significa que esteja surtindo efeitos, ou seja, que tenha eficácia. Os três conceitos, percebe-se, estão intimamente ligados. Segundo Maria Helena Diniz,

Terminada a fase constitutiva do processo de produção normativa, a norma já é válida; no período que vai de sua publicação até sua revogação, ou até o prazo estabelecido para sua validade, diz-se que a norma é vigente. $\mathrm{O}$ âmbito temporal de validade constitui o período durante o qual a norma tem vigência (sentido estrito). ${ }^{12}$

A autora ainda lembra que a norma que perdeu sua vigência por ter sido revogada poderá continuar tendo vigor para os casos anteriores a sua revogação e a produzir normalmente seus efeitos jurídicos por força das previsões constitucionais de respeito à coisa julgada, ato jurídico perfeito e direito adquirido (Constituição Federal de 1988, artigo $5^{\circ}$, XXXVI e lei de Introdução às Normas do Direito Brasileiro - decreto-lei 4657 de 04/09/1942 com redação dada pela lei 12376/2010, artigo $6^{\circ}$, $\S 1^{\circ}$ a $\left.3^{\circ}\right)$.

Para ela, o conceito de eficácia vem a ser a força que tem a norma jurídica vigente de produzir efeitos jurídicos concretos, o que implica não só a obediência a aspectos técnicos de elaboração da norma (elaboração por órgão competente e de acordo com os procedimentos legais estabelecidos), mas também de sua adequação à realidade e valores predominantes na sociedade.

A norma constitucional eficaz seria aquela que é cumprida e aplicada concretamente "por haver uma relação de adequação entre ela e o que sucede na realidade social e nos valores positivos." 13

\footnotetext{
${ }^{11}$ DINIZ, Maria Helena. Norma constitucional e seus efeitos. São Paulo: Saraiva, 2001, p.26.

${ }^{12}$ Idem, p.28.

${ }^{13}$ Ibidem, p.62.
} 
A eficácia diz respeito, portanto, ao fato de se saber se os destinatários da norma ajustam, ou não, seu comportamento em maior ou menor grau, às prescrições normativas, ou seja, se cumprem, ou não, os comandos jurídicos, se os aplicam ou não. [...] A eficácia de uma norma indica, em sentido técnico, que ela tem possibilidade de ser aplicada, de exercer, ou produzir, seus próprios efeitos jurídicos, porque se cumpriram as condições para isto exigidas (eficácia jurídica), sem que haja qualquer relação de dependência da sua observância, ou não, pelos destinatários. [...] É fato que, devido o teor de certas normas constitucionais, elas não podem produzir imediatamente efeitos jurídicos, ante a inexistência de uma regulamentação pretendidamente exigida por elas. ${ }^{14}$ (grifos nossos).

Para José Afonso da Silva, a eficácia jurídica de determinada norma significaria a qualidade de produzir efeitos jurídicos, em maior ou menor grau, quando a norma regula situações nela indicadas. ${ }^{15} \mathrm{O}$ autor, ao tratar das condições de aplicabilidade das normas constitucionais, estuda os conceitos de eficácia, legitimidade e vigência da norma jurídica. Sinteticamente, afirma José Afonso da Silva que vigência significa dizer que a "norma foi regularmente promulgada e publicada, com a condição de entrar em vigor em data determinada."16

Segundo ele, "a vigência é condição de efetivação da eficácia." ${ }^{17}$ Alegitimidade da norma significaria dizer que a norma está em conformidade com as disposições constitucionais. A eficácia seria a qualidade da norma de possuir todos os requisitos possibilitadores de sua aplicação. Para José Afonso da Silva,

Eficácia é a capacidade de atingir objetivos previamente fixados como metas. Tratando-se de normas jurídicas, a eficácia consiste na capacidade de atingir os objetivos nela traduzidos, que vem a ser, em última análise, realizar os ditames jurídicos objetivados pelo legislador. [...] O alcance dos objetivos da norma constitui a efetividade. ${ }^{18}$

Na visão de Andreas Joachim Krell sobre o tema

Por eficácia jurídica entendemos a capacidade (potencial) de uma norma constitucional para produzir efeitos jurídicos. A efetividade, por sua vez, significa o desempenho concreto da função social do Direito, representa a materialização, no mundo dos fatos, dos preceitos legais e simboliza a aproximação entre o dever-ser normativo e o ser da realidade social. ${ }^{19}$

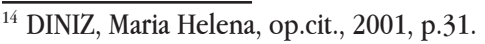

${ }^{15}$ SILVA, José Afonso da, op.cit., 2003, p.58.

${ }^{16}$ Idem, p.52.

${ }^{17}$ Ibidem, p.52.

${ }^{18}$ Ibidem, p.66.

${ }^{19}$ KRELL, Andreas J., op.cit., 2002, p.39.
} 
Ainda, José Afonso da Silva traz uma classificação das normas constitucionais quanto à eficácia. Dentre as várias classificações possíveis, a mais difundida e aceita pelos doutrinadores pátrios é a classificação de normas de eficácia plena, contida e limitada. Segundo ele

[...] são de eficácia plena as normas constitucionais que: a) contenham vedações ou proibições; b) confiram isenções, imunidades e prerrogativas; c) não designem órgãos ou autoridades especiais a que incumbam especificamente sua execução; d) não indiquem processos especiais de sua execução; e) não exijam a elaboração de novas normas legislativas que lhes completem o alcance e o sentido, ou lhes fixem o conteúdo, porque já se apresentam suficientemente explícitas na definição dos interesses nela regulados. ${ }^{20}$

As normas de eficácia plena seriam aquelas que estabelecem uma conduta, seja ela positiva ou negativa, com um comando certo e definido, que pode ser executado desde o momento em que a norma entra em vigor.

As normas de eficácia contida são aquelas que não surtem efeitos integralmente porque têm sua eficácia impedida por outra norma. Segundo José Afonso da Silva, quanto a essas normas "a legislação futura, antes de completar-lhes a eficácia, virá impedir a expansão da integridade de seu comando jurídico." ${ }^{21} \mathrm{~A}$ característica das normas de eficácia contida é que sua eficácia pode ser contida ou restringida por legislação futura ou outros meios. Exemplo de norma de eficácia contida encontra-se, por exemplo, no artigo 5, VIII da Constituição de $1988 .{ }^{22}$ Têm elas, portanto, natureza imperativa, sendo limitadoras do poder público.

Normas de eficácia contida, portanto, são aquelas em que o legislador constituinte regulou suficientemente os interesses relativos a determinada matéria, mas deixou margem à atuação restritiva por parte da competência discricionária do Poder Público, nos termos que a lei estabelecer ou nos termos de conceitos gerais nelas enunciados. ${ }^{23}$

Já em relação às normas de eficácia limitada ocorre o oposto: a legislação futura funcionará como meio de expandir o alcance da norma, tornando possível sua concretização. A doutrina do autor em referência divide as normas de eficácia

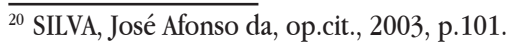

${ }^{21}$ Idem, p.103.

${ }^{22}$ Art. $5^{\circ}$, VIII :"ninguém será privado de direitos por motivo de crença religiosa ou de convicção filosófica ou política, salvo se as invocar para eximir-se de obrigação legal a todos imposta e recusar-se a cumprir prestação alternativa, fixada em lei."

${ }^{23}$ SILVA, José Afonso da. op.cit., 2003, p.116.
} 
limitada em dois grupos: normas declaratórias de princípios institutivos ou organizacionais e normas declaratórias de princípios programáticos.

As normas de eficácia limitada são "[...] aquelas que dependem de outras providências para que possam surtir os efeitos essenciais colimados pelo legislador constituinte. ${ }^{24}$ Enquanto as normas de eficácia limitada declaratórias de princípios institutivos têm como função primordial a organização, estruturação e regulação dos órgãos estatais, as normas de eficácia limitada declaratórias de princípios programáticos "envolvem um conteúdo social e objetivam a interferência do Estado na ordem econômico-social, mediante prestações positivas, a fim de propiciar a realização do bem comum, através da democracia social." 25

Tais normas seriam aquelas que traçam princípios para serem cumpridos pelos órgãos estatais, sem que haja regulação direta e imediata sobre as atividades a serem desenvolvidas. "São normas que não tiveram força suficiente para se desenvolver integralmente, sendo acolhidas, em princípio, como programa a ser realizado pelo Estado, por meio de leis ordinárias ou de outras providências." ${ }^{26}$ Elas traduzem os elementos sócio-ideológicos da Constituição, onde se acham os direitos sociais. ${ }^{27}$

Para explicar o que seriam as normas de eficácia limitada de conteúdo programático e suas ligações com os direitos sociais, especificamente direitos dos trabalhadores, José Afonso da Silva faz reflexões sobre o Estado liberal e o Estado social, afirmando que o embate entre ambos inseriu nas constituições contemporâneas princípios econômicos e sociais,

[...] comportando um conjunto de disposições concernentes tanto aos direitos dos trabalhadores quanto à estrutura da economia e ao estatuto dos cidadãos. $\mathrm{O}$ conjunto desses princípios forma $\mathrm{o}$ chamado conteúdo social das constituições. Vem daí o conceito de constituição-dirigente, de que a Constituição de 1988 é exemplo destacado, enquanto define fins e programas de ação futura no sentido de uma orientação social democrática. Por isso, ela, não raro, foi minuciosa e, no seu compromisso com as conquistas liberais e com um plano de evolução política de conteúdo social, o enunciado de suas normas assumiu, muitas vezes, grande imprecisão, comprometendo sua eficácia e aplicabilidade imediata, por requerer providências ulteriores para incidir concretamente. Muitas normas são traduzidas

\footnotetext{
$\overline{{ }^{4} 4}$ SILVA, José Afonso da. op.cit., 2003, p.118.

${ }^{25}$ Ibidem, p.125.

${ }^{26}$ Ibidem, p.151.

${ }^{27}$ Ibidem, p.139.
} 
no texto supremo apenas em principio, como esquemas genéricos, simples programas a serem desenvolvidos ulteriormente pela atividade dos legisladores ordinários. São estas que constituem as normas constitucionais de principio programático $[\ldots]^{28}$

São exemplos de normas de eficácia limitada declaratórias de princípios programáticos as contidas nos incisos XX e XXVII do artigo $7^{\circ}$ da Constituição Federal de 1988: "XX - proteção do mercado de trabalho da mulher, mediante incentivos específicos, nos termos da lei" e "XXVII - proteção em face da automação, na forma da lei." Vale trazer à baila as observações de Virgílio Afonso da Silva sobre o tema na obra "Direitos fundamentais: conteúdo essencial, restrições e eficácia". O referido autor aponta quais seriam os problemas do critério tríplice de classificação de José Afonso da Silva. Para ele, ao tratar das normas de eficácia contida haveria problema de ordem terminológica, sendo mais correto falar em normas contíveis, restringíveis ou dedutíveis posto que tal categoria de normas "exprime apenas uma possibilidade de contenção, de restrição." ${ }^{29}$ Aponta ainda que a classificação possível seria apenas dúplice e não tríplice, pois haveria apenas normas de eficácia plena e eficácia limitada. Por último indica um problema existencial, pois já que todas as normas constitucionais podem ser restringidas por legislação ordinária não haveria sentido distinguir entre normas que podem ou não podem ser restringidas.

Assim mesmo, importante ressaltar que Virgílio Afonso da Silva aponta o que entende serem os problemas da classificação de José Afonso da Silva, mas esclarece que tais problemas não abalam a classificação proposta. ${ }^{30}$

\section{O PROBLEMA DA EFICÁCIA E EFETIVIDADE DAS NORMAS DEFINIDORAS DE DIREITOS SOCIAIS TRABALHISTAS: PERSPECTIVAS TEÓRICAS NO BRASIL E NA ALEMANHA}

Os teóricos brasileiros ainda não aprofundaram ou formaram uma opinião definitiva ou concreta sobre o problema da eficácia e da aplicabilidade das normas constitucionais que consagram os direitos sociais.

\footnotetext{
${ }^{28}$ SILVA, José Afonso da. op.cit., 2003, p.136-137.

${ }^{29}$ SILVA, Virgílio Afonso da. Direitos fundamentais: conteúdo essencial, restrições e eficácia. 2.ed. Rio de Janeiro: Malheiros, 2017, p.220.

${ }^{30}$ Eis as palavras de Virgílio Afonso da Silva: "Mas é óbvio que nem o problema terminológico ("contida" vs. "restringível") nem o problema classificatório (classificação tríplice ou dúplice) abalam a classificação proposta por José Afonso da Silva. No máximo, ambas as críticas exigiriam algumas correções pontuais, que não alterariam, contudo, a classificação, em si, e seus objetivos." SILVA, Virgílio Afonso. op.cit., p.222.
} 
O próprio José Afonso da Silva, ao tratar dos direitos sociais relativos aos trabalhadores, reconhece que alguns direitos garantidos pelo artigo $7^{\circ}$ da Constituição de 1988 têm aplicabilidade imediata e que outros dependem de lei para sua efetivação.

São direitos dos trabalhadores os enumerados nos incisos do art. $7^{\circ}$, além de outros que visem à melhoria de sua condição social. Temos, assim, direitos expressamente enumerados e direitos simplesmente previstos. Dos enumerados, uns são imediatamente aplicáveis, outros dependem de lei para sua efetivação prática $[. ..]{ }^{31}$

O referido autor, entretanto, não se aprofunda no tema, limitando-se a afirmar que as normas que definem os direitos sociais "com eficácia imediata ou não, importam em obrigações estatais no sentido de proporcionar aos trabalhadores os direitos assegurados e programados. Toda atuação em outro sentido infringe-as." ${ }^{32}$

Na obra "Aplicabilidade das normas constitucionais", José Afonso da Silva chega a ser incongruente porque afirma, numa mesma passagem, a aplicabilidade imediata dos direitos individuais e a concepção de normas programáticas dos direitos sociais. ${ }^{33}$

Maria Helena Diniz, ao analisar o art. $7^{\circ}$, XXVII, da Constituição, que trata da proteção dos trabalhadores em face da automação na forma da lei, reconhece de maneira indireta tratar-se de norma programática, pois a própria Constituição está requerendo normação ulterior para possibilitar a executoriedade dessa norma. Diz a autora que "se determinar a necessidade de sua regulamentação, enquanto esta não advier, será sintaticamente ineficaz a norma constitucional, instaurando-se uma lacuna técnica." ${ }^{34}$

Segue a doutrinadora falando em lacunas normativas, axiológicas e ontológicas. A lacuna normativa inclui a lacuna técnica, e ocorre quando houver ausência de norma sobre determinado caso. A lacuna axiológica se dá caso haja norma que, ao ser aplicada, acarrete situação injusta - trata-se da inadequação do texto normativo em relação a um sistema de valores positivados. E a lacuna

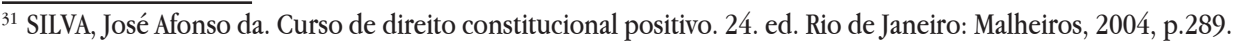

${ }^{32}$ Idem, p.289.

33 SILVA, José Afonso da, op. cit., 2003, p.140: "Pois as normas constitucionais que enunciam os direitos individuais são de aplicabilidade imediata e direta. [...] O problema que se coloca agudamente na doutrina recente consiste em buscar mecanismos constitucionais e fundamentos teóricos para superar o caráter abstrato e incompleto das normas definidoras de direitos sociais, ainda concebidas como programáticas, a fim de possibilitar sua concretização prática."

${ }^{34}$ DINIZ, Maria Helena, op.cit., 2001, p.40.
} 
ontológica se dá quando a norma vigente não corresponde à realidade fático-social, como ocorre quando o grande desenvolvimento tecnológico, por exemplo, acarreta o envelhecimento da norma ou seu descompasso com a realidade.

A concepção jurídica acerca das lacunas proposta por Maria Helena Diniz advém do fato de a autora ser adepta da teoria tridimensional do direito de Miguel Reale, segundo a qual a ciência do direito não deve ser estudada a partir de elementos estanques ou isolados, mas por meio de uma relação dinâmica e dialética entre os três elementos que a compõem de maneira indissociável: fato, valor e norma.

Impõe-se reconhecer a falta de técnica legislativa na elaboração do artigo $7^{\circ}$ da Constituição Federal de 1988 ou, no mínimo, a ingenuidade do constituinte. A crítica que se faz não é quanto à natureza exemplificativa do rol de direitos do $\operatorname{artigo} 7^{\circ}$, muito menos quanto à sua prolixidade. O que se critica é a impropriedade de afirmar a aplicabilidade imediata de todos os direitos e garantias fundamentais (art. $5^{\circ}, \S 1^{\circ} \mathrm{da}$ Constituição) quando isso não é factível.

Parte da doutrina nacional vem defendendo não existir qualquer problema neste tocante, expurgando assim os argumentos de que existe atecnia, lacuna técnica ou incompatibilidade entre o $\operatorname{art} .5^{\circ}, \S 1^{\circ}$ e os direitos fundamentais estatuídos no Título II, ambos da Constituição. A tese para defender tal posição é a de que a própria Constituição traz em seu bojo os denominados remédios constitucionais ou mecanismos supletivos da ausência de legislação infraconstitucional, que são as ações constitucionais que seriam capazes de solucionar tal impasse. José Afonso da Silva denomina tais ações de "instrumentos da eficácia constitucional." 35

Exemplo desta vertente teórica é Maria Helena Diniz. A autora reconhece que determinadas normas jurídicas são incapazes de produzir efeitos imediatos por conta de seu teor, o que nos levaria às reflexões sobre o status dos direitos sociais feitas nesse trabalho. Ainda assim, a autora afirma apenas que esse fato

[...] leva ao caso de uma possível incompletude da norma constitucional, pois a falta de disposição normativa por ela requerida colocanos diante do que se denomina, no plano teórico-científico, lacuna técnica ou intra legem, que ocorre quando houver ausência de uma norma cuja vigência é condição de eficácia de outra. ${ }^{36}$

O mandado de injunção é tido como ferramenta capaz de resolver as questões referentes a normas que, segundo a Constituição, têm aplicabilidade

\footnotetext{
35 SILVA, José Afonso da, op.cit., 2003, p.164.

${ }^{36}$ DINIZ, Maria Helena, op.cit., 2001, p.31.
} 
imediata, mas que, na prática, não passam de retórica. Diz o inciso LXXI do art. $5^{\circ}$ da Constituição:

conceder-se-á mandado de injunção sempre que a falta de norma regulamentadora torne inviável o exercício dos direitos e liberdades constitucionais e das prerrogativas inerentes à nacionalidade, à soberania e à cidadania.

A lei 13.300 de 23/06/2016 regulamentou o processo e julgamento dos mandados de injunção individual e coletivo. Por meio do mandado de injunção a parte provoca o Poder Judiciário para que este, reconhecendo o prejuízo sofrido pelo demandante, que não pode exercer direito constitucionalmente assegurado por falta total ou parcial de norma regulamentadora, determine ao Poder Legislativo que cumpra sua função primordial, que é a de legislar, para que o acionante possa usufruir de um direito que sempre foi seu.

Essa é a solução parcial apontada por Maria Helena Diniz, ao afirmar que no passado os problemas relativos a lacunas na Constituição só podiam ser resolvidos pelo próprio legislador, e que hoje isso não acontece mais porque o art. $5^{\circ}$, LXXI da Constituição, prevê que se houver lesão a direito individual pela inexistência de norma jurídica constitucionalmente requerida, deve-se recorrer ao mandado de injunção. ${ }^{37}$ Para ela, como o caso de algumas normas do artigo $7^{\circ}$ da Constituição é exemplo de lacuna técnica, ou seja, "ausência de norma imprescindível para que outra produza efeitos jurídicos, parece-nos que o órgão judicante deveria decidir por meio da integração, colmatando aquela lacuna." ${ }^{38}$

Para alguns autores, o mandado de injunção pode ser utilizado toda vez que se comprovar o nexo causal entre a omissão legislativa e a impossibilidade de exercer direitos constitucionalmente previstos.

Se o mandado de injunção realmente tivesse a capacidade de solucionar tais questões, ainda assim a atecnia constitucional que mostramos não deixaria de existir. Entretanto, como seus efeitos estariam mitigados, visto que o problema da efetivação do direito teria sido solucionado pelo mandado de injunção, poderíamos admitir o conformismo.

Porém, a doutrina constitucional brasileira afirma que o comando sentencial do mandado de injunção não tem o poder de obrigar o legislador a criar a norma

\footnotetext{
${ }^{37}$ DINIZ, Maria Helena, op.cit., 2001, p. 41.

${ }^{38}$ Ibidem, 2001, p.42.
} 
jurídica capaz de garantir a fruição do direito pelos interessados. A sentença não passa de uma carta de recomendação ao legislador. Tanto é assim que o artigo $8^{\circ}$ da lei 13.300/2016, regulamentadora do processo e julgamento do mandado de injunção, estabelece que na hipótese de reconhecimento da mora legislativa há dois caminhos a seguir: deferir a injunção para determinar prazo razoável para que o impetrado promova a edição da norma regulamentadora ou deferir a injunção para estabelecer as condições em que se dará o exercício dos direitos, das liberdades ou das prerrogativas reclamados ou, se for o caso, as condições em que poderá o interessado promover ação própria visando a exercê-los caso a mora legislativa não seja suprida no prazo determinado. O mandado de injunção $0^{39}$, portanto, não é a solução ideal para o problema da teoria da aplicabilidade imediata dos direitos sociais.

A tarefa integradora ou de colmatação de lacunas é criadora, no sentido de criar como explícito algo já implícito no sistema jurídico, estabelecendo-se uma norma individual relativa à hipótese não regulamentada, submetida à apreciação do Judiciário. Não cria direito novo, mas apenas uma norma individual, que se aplica só ao caso que lhe deu origem. [...] Entendemos que a integração da lacuna não se situa no plano legislativo nem é uma delegação legislativa ao juiz; ela não cria novas normas jurídicas gerais, mas individuais, que só poderão ascender à categoria de normas jurídicas gerais, tãosomente em virtude de um subseqüente processo de recepção e absorção dessas normas por uma lei ou jurisprudência, uma vez que as súmulas do Tribunal são tidas como normas gerais. Fácil é denotar que a integração pode colmatar as lacunas, mas não pode instaurar uma completude necessária, no sentido de garantir que todo comportamento possível tenha um status deôntico. A jurisdição é supletiva, integra a norma, mas a lacuna permanece. A decisão soluciona a questão sem eliminá-la; apenas pode por fim ao conflito, que não mais poderá ser retomado no plano institucional (coisa julgada). ${ }^{40}$

José Afonso da Silva aborda o problema de maneira breve e de forma conciliatória, afirmando que

O Título II da Constituição contém a declaração dos direitos e garantias fundamentais, incluindo aí os direitos individuais, coletivos, sociais, de nacionalidade e políticos. $\mathrm{O}$ art. $5^{\circ}, \S 1^{\circ}$, por seu lado, es-

\footnotetext{
${ }^{39}$ Vide os Mandados de Injunção 670, 708 e 712 sobre direito de greve no STF e MI 795 sobre aposentadoria especial do servidor público. Recentemente, em abril/2017, o STF proferiu decisão que proibiu a greve de policiais militares conforme artigo 142 da Constituição.

${ }^{40}$ DINIZ, Maria Helena, op.cit., 2001, p.43-44.
} 
tatui que 'as normas definidoras dos direitos e garantias fundamentais tem aplicação imediata.' Isso abrange, pelo visto, as normas que revelam os direitos sociais, nos termos dos arts. $6^{\circ}$ a 11 . Isso, contudo, não resolve todas as questões, porque a Constituição mesma faz depender de legislação ulterior a aplicabilidade de algumas normas definidoras de direitos sociais e coletivos. Por regra, as normas que consubstanciam os direitos fundamentais democráticos e individuais são de eficácia contida e aplicabilidade imediata, enquanto as que definem os direitos sociais tendem a sê-lo também na Constituição vigente, mas algumas, especialmente as que mencionam uma lei integradora, são de eficácia limitada e aplicabilidade indireta. ${ }^{41}$

Há de se reconhecer que determinados direitos (como se vê entre o elenco dos direitos sociais) têm, a despeito de sua natureza de direitos fundamentais, característica de normas programáticas. Assim acontece, por exemplo, com a garantia de proteção do mercado de trabalho da mulher (art. $7^{\circ}, \mathrm{XX}$ ), adicional de remuneração para as atividades penosas (art. $7^{\circ}, \mathrm{XXIII)}$, proteção em face da automação (art. $7^{\circ}$, XXVIII).

Sobre o problema da falta de efetividade das normas laborais, Antonio Casimiro Ferreira alerta que

[...] apesar dos aspectos positivos que o direito do trabalho carreou para as relações sociais, podemos considerar que em grande medida o seu projecto permanece inconcluído. A progressiva perda de sentido do direito do trabalho, imposta pelos poderes de facto ou sustentada teórica e politicamente pelas perspectivas neoliberais e neoclássicas que pretendem recivilizá-lo, ou pura e simplesmente extingui-lo, desvela com grande clareza os limites inscritos no seu código genético associados quer à tensão entre democracia e capitalismo quer à tensão entre os princípios da emancipação e da regulação. ${ }^{42}$

Parte da doutrina estrangeira já faz esta afirmação, como se vê em Norberto Bobbio $^{43}$, Ernst Forsthoff ${ }^{44}$, Ernst-Wolfgang Böckenforde ${ }^{45}$ e Antonio Enrique Perez Luño. ${ }^{46}$

$\overline{41}$ SILVA, José Afonso da, op.cit., 2003, p.165.

${ }^{42}$ FERREIRA, Antonio Casimiro. Para uma concepção decente e democrática do trabalho e dos seus direitos: (re) pensar o direito das relações laborais. In: SANTOS, Boaventura de Souza (Org.). A globalização e as ciências sociais. 2. ed. São Paulo: Cortez, 2002, p.282.

${ }^{43}$ BOBBIO, Norberto, op.cit., 1992, p.77-78.

${ }^{44}$ FORSTHOFF, Ernst, Rechsstaat im Wandel: Verfassungsrechtliche Abhandlungen 1954-1973. Tradução de Günther Maluschke. 2. Auflage, Verlag C.H.Beck, Munchen, 1976, p.76.

${ }^{45}$ BÖCKENFÖRDE, Ernst-Wolfgang. Staat, Verfassung, Demokratie : Studien zur Verfassungstheorie und zum Verfassungsrecht. Tradução de Günther Maluschke. 2. Aufl. Frankfurt am Main: Suhrkamp, 1992, p.154.

${ }^{46}$ PEREZ LUÑO, Antonio Enrique. Derechos humanos, Estado de Derecho y Constitución. 5. ed. Madri: Tecnos, 1995,p. 83. 
A doutrina alemã chama atenção para o fato de que não se pode pensar nos direitos sociais como aplicáveis indiscriminadamente a todo tipo de situação ou sujeito. Esse é o detalhe percebido pela doutrina estrangeira e que ainda não foi analisado pela doutrina brasileira.

Interessante notar que diferentemente do Brasil, no qual a Constituição de 1988 inseriu 34 incisos tratando dos direitos dos trabalhadores, a lei Fundamental Alemã não contém um catálogo de direitos fundamentais sociais, limitando-se a assegurar os direitos fundamentais clássicos de primeira geração como liberdade, propriedade e igualdade. ${ }^{47}$

Edilton Meireles trata o tema ao comentar sobre a Constituição Alemã:

Aliás, a realidade alemã demonstra que não importa a dimensão quantitativa dos direitos fundamentais dos trabalhadores estabelecidos na Constituição se for, na prática, fraca ou inexpressiva a sua eficácia. O que importa, em verdade, é verificar até que ponto os direitos fundamentais são efetivos e se podem ser demandados em juízo. E, neste aspecto, apesar das poucas regras dirigidas a reger o direito do trabalho, a realidade alemã demonstra que o que interessa não é a quantidade, mas, sim, a eficácia dos direitos fundamentais, ainda que partindo de uma interpretação ampla dos princípios constitucionais, de modo a alcançar o seio do direito do trabalho. ${ }^{48}$

$\mathrm{Na}$ visão de Forsthoff, os direitos sociais são direitos de participação, e não são padronizados ou idênticos. Por tal razão, precisariam, para ser aplicados, de graduação e diferenciação para cada caso particular. O simples fato de que a medida ou proporção dos direitos sociais deveria ser deixada aos critérios da legislação e da administração competentes para a execução da lei excluiria a tese de aplicação imediata desses direitos. Ou seja: para a execução dos direitos sociais há de se contemplar que os mesmos possuem características ou necessidades específicas, que devem ser apreciadas caso a caso pelo órgão competente.

Para Forsthoff, é por essa razão que os direitos sociais como o direito ao trabalho, educação, proteção à família, dentre outros, não são concebíveis como normas abstratas e executáveis. Para ele, as matérias tratadas pelos direitos sociais não estão no estado de perfeição normativa que se pressupõe necessário para fins de execução jurídica.

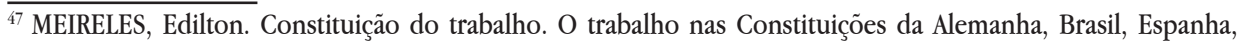
França, Itália e Portugal. 2.ed. São Paulo: LTr, 2014, p.70.

${ }^{48} \mathrm{Idem}, \mathrm{p} .70$.
} 
Partindo de uma perspectiva técnica, Maria Helena Diniz afirma existir uma teoria da bipolaridade eficacial. No caso em apreço, estaríamos tratando de um fenômeno eficacial positivo parcial que ocorre

[...] não só quando o constituinte, para atender questões políticas, posterga, ou suspende, os efeitos do texto constitucional para o futuro, instaurando uma lacuna técnica, ou quando emite norma constitucional ad pompam vel ostentationem, mesmo tendo consciência de sua desobediência pelo destinatário, com fins puramente retóricos, como também quando os órgãos com competência normativa, em sua atividade executiva, legislativa e jurisdicional, desobedecem ao seu comando, ora omitindo-se de normar, não estabelecendo a regulamentação futura, requerida para preencher aquela lacuna técnica ora não o aplicando por desatender aos reclamos da realidade social-fática a que se refere e dos valores positivos vigentes na sociedade que a rege, instaurando, respectivamente, a lacuna ontológica e a axiológica. ${ }^{49}$ (destaques no original)

Duas grandes questões se colocam ao abordar o tema relativo aos direitos sociais para Böckenförde: uma diz respeito à ideia dos direitos fundamentais sociais como direitos constitucionais e outra relativa à realização jurídico-prática dessa ideia no sistema de uma Constituição de um Estado democrático de Direito. Quanto a este problema, o autor também defende a impossibilidade estrutural de fruição imediata dos direitos sociais. Ele explica que tais direitos "se dirigem, na sua validade imediata, aos órgãos estatais da legislação e administração e os obrigam a cumprir um mandado neles contido." ${ }^{\text {0 }}$ Assim, antes de sua fruição ou execução, há necessidade de explicitação de seu conteúdo e de definição de seu modo de financiamento.

Para exemplificar o alcance da questão, o autor diz que

Se os direitos liberais também garantem as condições prévias sociais da possibilidade de sua realização como pretensão imediata de direito fundamental, então, a liberdade de religião significaria ao mesmo tempo a responsabilidade do Estado pelos meios econômicos da existência das comunidades religiosas; a liberdade de imprensa implicaria a obrigação estatal para manter as condições prévias econômicas do pluralismo da imprensa (por cláusula de omissão de concorrência, subvenção e outras coisas); a liberdade de coalizão significaria ao mesmo tempo o financiamento dos sindicatos pelo Estado; a livre escolha dos centros de instrução significaria ao mes-

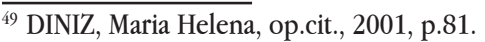

${ }^{50}$ BÖCKENFÖRDE, Ernst-Wolfgang, op.cit., 1992, p.153. 
mo tempo a obrigação do Estado de criar capacidades de instrução suficientes para desejos de profissão individuais sem exame de necessidades. ${ }^{51}$

Pode uma impossibilidade econômica servir de limite para o exercício de um direito fundamental? A resposta, em tese, seria não, haja vista toda a teoria dos direitos fundamentais. Entretanto, na realidade, é assim que tem acontecido. A fruição ou execução de direitos fundamentais sociais tem encontrado limitações de ordem econômica. A incapacidade do Estado de garantir os meios financeiros de consecução dos direitos fundamentais tem impedido sua garantia, existência e fruição. E mais - tal incapacidade tem gerado discussões sobre a interpretação dos direitos fundamentais e sobre as prioridades estatais.

Ao tratar do controle judicial da realização dos direitos sociais, José Joaquim Gomes Canotilho também aponta para o problema de forma crítica ao estatuir que referido controle tem "um ponto de partida metódico não inteiramente aceitável: a de que as concretizações legislativas de direitos derivados a prestações, indissociáveis da realização efectiva dos direitos sociais, assentam, na prática, em critérios de oportunidade técnico-financeira e política." 52

Aqui caberia discutirmos a teoria da "reserva do possível", oriunda do direito alemão. Ao interpretar o artigo 12, inciso I, da lei fundamental daquele país, o Supremo Tribunal da República Federal da Alemanha reconheceu um problema de estrutura dos direitos fundamentais sociais e delimitou o gozo dos direitos fundamentais sociais na medida em que fosse possível ao Estado garantir, em seu orçamento, a verba necessária para sua fruição. A Constituição turca resolveu o problema estabelecendo o seguinte no artigo 53 de seu texto: "O Estado exercerá suas tarefas para atingir as metas sociais e econômicas apresentadas nesse parágrafo na medida em que o desenvolvimento econômico e as fontes de dinheiro a sua disposição lhe permitirem isso." ${ }^{53}$

Por conseguinte, os direitos fundamentais sociais no quadro de uma ordem do Estado de Direito democrático não podem ter o caráter de direitos fundamentais no sentido próprio, porque isto requer a validade imediata e a possibilidade para o cidadão de perseguir seu direito por meio de ação judicial; isto, porém, não significa que eles devem permanecer enunciados programáticos políticos sem compromisso. Sua realização prático-jurídica apropriada no nível da constituição é - como as reflexões anteriores mostraram claramente

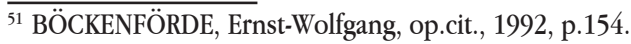

${ }^{52}$ CANOTILHO, J.J. Gomes. Direito constitucional e teoria da Constituição. 7.ed. Lisboa: Almedina, 2003, p.520.

${ }^{53}$ BÖCKENFÖRDE, Ernst-Wolfgang, op.cit., 1992, p.155.
} 
- a forma de mandado constitucional. Mandados constitucionais são obrigações jurídicas objetivas endereçadas a órgãos estatais, a saber, legislação e administração. Tais órgãos tem a obrigação de elaborar e aplicar medidas adequadas para realizar a meta ou programa formulado no mandado; o caminho, as proporções e as modalidades de realização são, em primeiro lugar, deixados à discrição dos órgãos ativos e, com isto, ao processo político. ${ }^{54}$

O texto de Böckenförde faz-nos concluir que os "mandados constitucionais" não se confundem com os direitos fundamentais, pois estes são de fruição imediata, enquanto os primeiros dependem de normação ulterior. Assim, os referidos "mandados constitucionais" seriam o equivalente brasileiro das normas programáticas, ou seja, normas que contêm as diretrizes de um programa a ser cumprido pelo legislador. Sobre essa terminologia, interessante o esclarecimento que faz Andreas Joachim Krell, ao explicar que a não inclusão de direitos sociais na lei fundamental alemã não significa recusa ao ideário ligado a esses direitos, mas antevê o problema de sua efetivação. Por isso "a doutrina alemã se refere a essas normas constitucionais como 'mandados' (Aufräge) e não propriamente 'direitos". ${ }^{5}$.

Idêntica conclusão podemos alcançar ao ler o texto de Ernst Forsthoff, que exclui a hipótese de aplicabilidade imediata dos direitos sociais porque estes

[...] precisam de graduação e diferenciação, porque tem sentido razoável só nos limites daquilo que é apropriado, necessário e possível no caso particular. A determinação desta proporção (medida) deve ser deixada aos critérios da legislação e da administração competente para a execução da lei. ${ }^{56}$

No Brasil, os adeptos da teoria do "mínimo existencial" seguem a mesma linha dos pensadores alemães. Defende-se "o mínimo existencial como o direito à prestação mínima de segurança social abaixo da qual o homem não sobrevive com as suas características de humanidade." ${ }^{.57}$

Quanto a isso, interessante o pensamento de Vicente de Paulo Barretto, que de logo identifica esse argumento como falacioso. Diz ele que este argumento também se denomina "reserva do possível" e

[...] ignora em que medida o custo é consubstancial a todos os di-

\footnotetext{
${ }^{54}$ BÖCKENFÖRDE, Ernst-Wolfgang, op.cit., 1992, p.156.

${ }^{55}$ KRELL, Andreas J., op.cit.,2002,p.48.

${ }^{56}$ FORSTHOFF, Ernst, op.cit.,1976,p.75.

${ }^{57}$ TORRES, Ricardo Lobo. A metamorfose dos direitos sociais em mínimo existencial. In: SARLET, Ingo Wolfgang (Org.). Direitos fundamentais sociais: estudos de direito constitucional, internacional e comparado. Rio de Janeiro: Renovar, 2003, p. 9.
} 
reitos fundamentais. Não podemos nos esquecer do alto custo do aparelho estatal administrativo-judicial necessário para garantir os direitos civis e políticos. Portanto, a escassez de recursos como argumento para a não observância dos direitos sociais acaba afetando, precisamente em virtude da integridade dos direitos humanos, tanto os direitos civis e políticos, como os direitos sociais. Estabelecer uma relação de continuidade entre a escassez de recursos públicos e a afirmação de direitos acaba resultando em ameaça à existência de todos os direitos. ${ }^{58}$ (grifos nossos)

Para ele "a presença do poder público na implementação dos direitos sociais independe de mais ou menos recursos públicos, mas encontra-se diretamente ligada à função principal do Estado na sociedade moderna, qual seja, assegurar o bem comum." 59

Assim, a solução encontrada por essa vertente teórica seria a de limitar a fruição ou garantia de exequibilidade dos direitos fundamentais à existência de recursos orçamentários para tanto.

Robert Alexy também tocou nesse problema, afirmando que También los derechos fundamentales sociales mínimos tienen considerables efectos financieros cuando son muchos quienes los hacen valer. Sin embargo, esto solo no justifica inferir la no existência de estos derechos. [...] Derechos individuales pueden tener mas peso que las razones de politica financiera. ${ }^{60}$

Alguns doutrinadores defendem, ainda, que um dos obstáculos à efetivação dos direitos sociais é a inadequação dos mecanismos processuais tradicionais para a tutela dos direitos sociais.

Outro obstáculo importante para la exigibilidad de los derechos sociales es la inadecuación de los mecanismos procesales tradicionales para su tutela. Las acciones judiciales tradicionales tipificadas por el ordenamiento jurídico han sido pensadas para la protección de los derechos civiles clásicos. 61

Resta-nos, pois, admitir que a afirmação constitucional de aplicação imediata

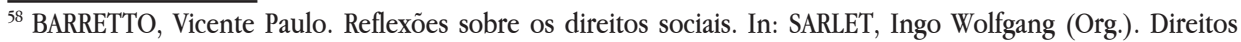
fundamentais sociais : estudos de direito constitucional, internacional e comparado. Rio de Janeiro: Renovar, 2003, p. 121.

${ }^{59}$ Idem, p.120.

${ }^{60}$ ALEXY, Robert. Teoria de los derechos fundamentales. Madrid: Centro de Estúdios Constitucionales, 1993, p. 495.

${ }^{61}$ ABRAMOVICH, Victor ; COURTIS, Christian. Apuntes sobre la exigibilidad judicial de los derechos sociales. In: SARLET, Ingo Wolfgang (Org.). Direitos fundamentais sociais : estudos de direito constitucional, internacional e comparado. Rio de Janeiro: Renovar, 2003, p.161.
} 
dos direitos fundamentais sociais é meramente retórica, e que há, neste ponto, um defeito de técnica legislativa. Se não se tratar de retórica, poderíamos afirmar que tais preceitos constitucionais podem pretender não sua obediência imediata, mas assegurar um ponto de vista ideológico.

Neste aspecto vale mencionar o posicionamento de Andreas Joachim Krell, que mostra que a doutrina portuguesa utilizou-se das teorias do direito alemão e que muitos doutrinadores brasileiros simplesmente transpuseram referidas teorias (como reserva do possível e mínimo existencial) para o direito brasileiro.

$\mathrm{O}$ professor alemão condena tal prática, dizendo que não condiz com os verdadeiros preceitos do direito comparado e demonstra que a decisão do tribunal alemão não poderia simplesmente ser transposta para o Brasil, seja por se tratar de um país de realidade completamente distinta da Alemanha, ou por causa das diferenças nos sistemas jurídicos dos dois países, seja por causa da flagrante incompatibilidade de aplicação no Brasil.

Para Andreas Joachim Krell

essa teoria, na verdade, representa uma adaptação de um topos da jurisprudência constitucional alemã (Der Vorbehalt dês Möglichen) que entende que a construção de direitos subjetivos à prestação material de serviços públicos pelo Estado está sujeita à condição da disponibilidade dos respectivos recursos." ${ }^{22}$

Para corroborar as afirmações de Andreas Joachim Krell, citamos as lições de Jorge Reis Novais:

Sobre este modelo, diga-se, preliminarmente, que uma teorização deste tipo, pura e simplesmente identificadora dos direitos sociais com mínimo existencial, reduzindo a essa dimensão toda a força jurídica dos direitos sociais enquanto direitos fundamentais e, ainda assim, com as reservas e a contenção de controlo judicial assinaladas, pode ser perfeitamente admissível numa Constituição sem direitos sociais, como a alemã. Compreende-se, com efeito, que o direito a um mínimo existencial tenha sido jurisprudencialmente desenvolvido na Alemanha, onde a ausência constitucional de direitos sociais estimula a busca de alternativas mínimas de garantia jurídico-constitucional dos interesses individuais (...). No fundo, dada a ausência constitucional dos direitos sociais, aquilo que o Tribunal Constitucional alemão fez foi criar um mínimo de proteção jurídica de natureza constitucional, portanto, uma garantia mínima que se impu-

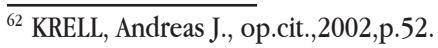


sesse e condicionasse o próprio legislador. Mas, será esse modelo compatível com Constituições, como a portuguesa ou a brasileira, que consagram na qualidade de direitos fundamentais um elenco pormenorizado e desenvolvido de direitos sociais? Qual seria, então, o sentido útil da consagração de direitos sociais por parte dessas Constituições se tudo ficava apenas reduzido ao mínimo exigido pela dignidade da pessoa humana? ${ }^{33}$

Concordamos com o ponto de vista de Andreas Joachim Krell e Jorge Reis Novais, mormente porque a adoção da teoria da reserva do possível, limitando a fruição de direitos fundamentais à existência de previsão orçamentária ou provisão suficiente de recursos monetários, embora seja uma situação fática possível, não autorizaria a rejeição da fruição destes direitos nem a preferência na fruição de outros. A adoção, portanto, da teoria da reserva do possível significaria a admissão do retrocesso social.

Ainda explicando a teoria da reserva do possível e sua aplicação na Alemanha, Andreas Joachim Krell mostra que a decisão obedeceu à análise de um caso concreto específico, e que nele o Tribunal Constitucional Federal da Alemanha decidiu que os direitos a prestações positivas (Teilhaberechte) "estão sujeitos à reserva do possível no sentido daquilo que o indivíduo, de maneira racional, pode esperar da sociedade. ${ }^{\circ 4}$ Indubitável que aquilo que se considera socialmente razoável na Alemanha não o será no Brasil, que possui padrões de qualidade e tempo de vida muito inferiores ao dos países europeus em geral.

A conclusão do autor sobre a aplicação da teoria da reserva do possível no Brasil, a qual nos filiamos, é de que referida teoria não pode ser aplicada no Brasil para resolver o problema da eficácia dos direitos fundamentais trabalhistas, seja porque fruto da má interpretação da decisão original, seja porque condicionar a realização de direitos sociais à existência de recursos financeiros do Estado significa reduzir a eficácia de tais direitos a zero. ${ }^{65}$ Sobre os direitos sociais na Constituição alemã, afirma Andreas Joachim Krell que

A Lei Fundamental da República Federal da Alemanha (de 1949) não incorporou nenhum ordenamento sistemático dos direitos sociais da 'segunda geração' (dos trabalhadores, educação, saúde, assistência, etc.), fato que se deve às más experiências com a Carta anterior de

\footnotetext{
${ }^{63}$ NOVAIS, Jorge Reis. Direitos sociais teoria jurídica dos direitos socais enquanto direitos fundamentais. 2.ed. Lisboa: AAFDL, 2016, p.233-234.

${ }^{64}$ KRELL, Andreas J., op.cit.,2002,p.52.

${ }^{65}$ Idem, p.54.
} 
Weimar. Essa Constituição de 1919 é tida, no mundo inteiro, como uma das primeiras Cartas que incorporaram os direitos sociais a prestações estatais no seu texto. No entanto, para a doutrina constitucional alemã pós-guerra, ela serve como modelo de uma Carta 'fracassada' [...] Os modernos artigos da Carta de Weimar sobre direitos sociais foram 'ridicularizados' por parte dos integrantes da extrema-direita e esquerda política, como 'promessas vazias do Estado burguês' e 'contos de lenda'. Como consequência, o legislador fundamental de 1949 renunciou deliberadamente à formulação de normas que conferem direitos subjetivos a prestações positivas por parte do Estado. Os direitos sociais, cuja eficácia sempre depende de vários fatores econômicos e políticos, ficaram de fora. ${ }^{66}$

$\mathrm{O}$ autor, diferentemente do que afirmamos aqui, defende sim a eficácia imediata dos direitos fundamentais sociais sustentando, dentre outros argumentos, que "limitar normas constitucionais a expressar a realidade de fato seria a sua negação." ${ }^{167}$ Para ele, a Constituição do Brasil representaria uma constituição nominal, sendo aquela cujas normas ainda não estão sendo acompanhadas pelo processo político. Referido problema seria solucionado com o tempo, por meio do processo de maturação e desenvolvimento da própria sociedade. Para os adeptos desta corrente, "[...] promessas exageradas em normas constitucionais de cunho social significam, acima de tudo, um estímulo aos detentores do poder para a sua realização e uma fonte de esperança para os formalmente beneficiados." ${ }^{18}$ Para Andreas Joachim Krell, os direitos fundamentais sociais da Constituição Brasileira de 1988 tem função, acima de tudo, conscientizadora.

Informa, ainda, Andréas Joachim Krell que a maioria dos autores alemães se posiciona contra a existência de direitos fundamentais sociais no corpo da Constituição porque estes seriam, na sua maioria, não realizáveis na atualidade pelo Estado, provocando a impressão no cidadão de que todo o texto constitucional não passaria de uma construção de frases ou um "catecismo popular cheio de utopias, que resultaria na perda da normatividade da Carta e da sua força de estabelecer valores." ${ }^{69}$

Para José Afonso da Silva, a relevância das normas programáticas também está no sentido teleológico, pois apontam para os fins futuros e servem de pauta de

\footnotetext{
${ }_{66}$ KRELL, Andreas J., op.cit.,2002, p.45.

${ }^{67}$ Ibidem, p. 25.

${ }^{68}$ Ibidem, p. 27.

${ }^{69}$ Ibidem, p. 46.
} 
valores para movimentos que queiram ver tais fins aplicados e cumpridos. ${ }^{70}$

Acreditamos na função conscientizadora dos direitos fundamentais. Mais especificamente no que diz respeito aos direitos sociais dos trabalhadores, entendemos que sua função tem ainda mais relevo no panorama dos direitos fundamentais, haja vista as razões de cunho histórico que motivaram sua inserção no texto constitucional. No entanto, o exagero do constituinte e a ineficácia de alguns desses direitos provocam descrédito nos cidadãos.

Na Alemanha, como no Brasil, se reconhece que promessas constitucionais exageradas mediante Direitos Fundamentais Sociais sem a possibilidade real da sua realização são capazes de levar a uma 'frustração constitucional' (Verfassungsenttäuschung), o que acaba desacreditando a própria instituição da constituição como sistema de normas legais vigentes e pode abalar a confiança dos cidadãos na ordem jurídica como um todo. No entanto, a frustração e a desconfiança que essas proclamações solenes, carentes de eficácia, possam provocar, não autoriza a abordar essa questão em termos de um utopismo ingênuo ou um voluntarismo irreflexivo. ${ }^{71}$

Andreas Joachim Krell conclui que a eficácia social reduzida dos direitos fundamentais sociais no Brasil não se deve à falta de leis ordinárias, pois o problema maior é a não prestação real dos serviços sociais básicos pelo Poder Público.

Mantém-se, portanto, a linha mestra de pensamento de que os direitos sociais constituem direitos a prestações materiais do Estado, prestações positivas concebidas para atenuar as desigualdades de fato na sociedade. Em face da realidade do mau funcionamento dos serviços essenciais para o bem-estar da população, devem ser adotadas políticas públicas que visem a proteger determinadas categorias sociais marginalizadas e economicamente excluídas. Referidas políticas públicas necessitam de um hábil gerenciamento pelo Estado, que pode realizar sua implementação, inclusive, com o auxílio da sociedade civil. ${ }^{72}$

Contrariando a teoria da reserva do possível, afirma Andreas Joachim Krell que

os direitos fundamentais de defesa somente podem ser eficazes quando protegem, ao mesmo tempo, as condições materiais mínimas necessárias para a possibilidade da sua realização. Especialmente na área dos direitos básicos da vida e da integridade física, as

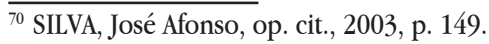

${ }^{71}$ KRELL, Andreas J., op.cit., 2002, p.26.

${ }^{72}$ Idem, p.34.
} 
prestações positivas do Estado para a sua defesa não podem ficar na dependência de viabilidade orçamentária. ${ }^{73}$

O problema da eficácia dos direitos trabalhistas, considerando-os como aqueles constantes do rol do artigo $7^{\circ}$ da Constituição de 1988, não apresenta solução simples. Não duvidamos que os direitos dos trabalhadores sejam direitos sociais fundamentais, segundo o ordenamento jurídico brasileiro. Entretanto, quanto ao tema de sua eficácia, continuamos defendendo que o fato de a Carta Magna dispor de maneira expressa que tais direitos têm eficácia imediata não é suficiente para transformar sua natureza.

Este argumento ou constatação não retira a importância histórica do reconhecimento e inserção no corpo da Constituição dos direitos trabalhistas, mas privilegia uma visão menos ideológica. Também não significa que só sejam fundamentais aqueles direitos dotados de eficácia imediata, nem que direitos fundamentais que não tenham eficácia imediata tenham menos importância ou configurem uma categoria de menor qualidade. Nesse sentido, é importante o posicionamento de Antonio Enrique Perez Luño, ao afirmar que

[...] sustraer los derechos sociales del marco constitucional de positviación de los derechos fundamentales implica, de um lado, consagrar la fractura entre libertades publicas y derechos sociales, propia de la lógica individualista; y de outro, privarles, com el pretexto de sua mejor regulación técnica em la legislación ordinária, de sua carácter ejemplar y fundamental[...]Es evidente que los derechos sociales, como todos los derechos fundamentales, se ballan sujetos a uma paulatina transformacion em la medida e que varían aãs condiciones socioeconomicas sobre las que se asientan. Abora bien, esto no es motivo para desconstitucionalizarlos, ya que ello supondria dejar al margen de la ley fundamental uno de los aspectos más importantes que, precisametne, está llamada a reglamentar. ${ }^{74}$ (grifos nossos)

Tem razão Martônio Mont'Alverne Barreto Lima ao dizer que é razoável admitir que a Constituição de 1988 nasceu no contexto histórico marcado pelo desejo de renovação. Trata-se de análise similar a formulada por Andreas Joachim Krell ao tratar da função conscientizadora dos direitos fundamentais insertos na Constituição de 1988.

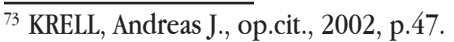

${ }^{74}$ PEREZ LUÑO, Antonio Enrique. op.cit., 1995, p.89.
} 
Se o quadro político do desempenho da Constituição tem deixado a desejar, por outro lado e sob a ótica de uma construção de teoria da democracia é importante lembrar que a permanência de seu quadro de direitos e garantias e de seu complexo mecanismo de intercomunicação entre os diversos assuntos autorizam que esta mesma Constituição preencha sua função primordial de progresso político de uma sociedade. Refiro-me aqui ao pensamento de Peter Häberle, que, ao saudar as Constituições da redemocratização latino-americanas, amplamente criticadas por um rol de direitos e garantias inexeqüíveis para a realidade destas nações, afirma que: 'A cínica referência aos 'déficits' da realidade constitucional dos países do Terceiro Mundo desconhece a genuína contribuição dos 'pequenos' países em desenvolvimento e suas possibilidades de 'recuperar-se' no 'futuro'. [...] O texto progressista permanece, então, como uma advertência provocadora a todos. E também os clássicos elementos dos textos do Estado constitucional forma um dia, em parte, utopias. ${ }^{, 75}$

No mesmo sentido opina Jorge Pinheiro Castelo.

A democracia , para funcionar, precisa de uma visão, de utopia - um caminho para a sociedade melhor. A ausência de uma visão de futuro estabelece a paralisia social e econômica. Os Estados perdem a capacidade de impor custos sobre os cidadãos e realizar tarefas que iriam melhorar a vida da pessoa média. ${ }^{76}$

O que defendemos é que, embora destituídos de eficácia imediata, determinados direitos trabalhistas continuam a ser direitos fundamentais, a ter grande importância e a constituir, nos termos da doutrina que trata das normas de eficácia limitada, um projeto ou programa a ser alcançado no futuro. Devemos reconhecer que o problema da eficácia dos direitos fundamentais trabalhistas passa não só pelo problema da eficácia jurídica dessas normas, mas também por profundos problemas ligados à cultura de nosso povo, do empresariado brasileiro, dos legisladores e dos juízes que aplicam o direito.

Outra tese que poderíamos adotar é a de que o constituinte não foi atécnico ou ingênuo ao conferir eficácia imediata aos direitos fundamentais, pois esse foi o caminho que encontrou para evitar o conformismo dos intérpretes do direito e incentivar a criação de normas e interpretações que visassem à garantia da fruição de tais direitos.

\footnotetext{
${ }^{75}$ LIMA, Martônio Mont'Alverne Barreto. Voto secreto nos Legislativos Estaduais e Municipais, ou de como as coisas podem mudar. In: CAVALCANTE, Ronald Soares (Org.). Estudos de Direito Constitucional: Homenagem a Paulo Bonavides. São Paulo: LTr, 2001,p.371-372.

${ }^{76}$ CASTELO, Jorge Pinheiro. O direito material e processual do trabalho e a pós-modernidade: a CLT, o CDC e as repercussões do Novo Código Civil. São Paulo: LTr, 2003, p.104.
} 
A solução proposta por Robert Alexy passa pela ponderação entre princípios e interpretação das normas jurídicas:

[...] la cuestión acerca de cuáles son los derechos fundamentales sociales que el individuo posee definitivamente es una cuestión de la ponderación entre princípios. [...] La respuesta detallada a esta cuestión es tarea de la dogmática de los diferentes derechos fundamentales sociales. ${ }^{77}$

A doutrina brasileira tem se inclinado cada vez mais no sentido de indicar que a solução para o problema da efetividade dos direitos sociais trabalhistas está na interpretação constitucional e de uma postura mais corajosa e ativa por parte dos membros do Poder Judiciário ao efetuar essa interpretação.

Edilton Meireles adota essa postura e defende que os direitos fundamentais dos trabalhadores tem eficácia imediata. Ao formalizar o contrato de trabalho, as partes (empregado e empregador) devem dispor sobre a efetividade dos direitos fundamentais trabalhistas e, se houver omissão quanto a isso, devem recorrer ao Poder Judiciário para que se manifeste sobre o tema e colmate a lacuna jurídica.

\section{CONSIDERAÇÕES FINAIS}

A Constituição da República Federativa do Brasil, promulgada em 1988, foi revolucionária no que diz respeito à inserção de uma série de direitos voltados aos trabalhadores, conferindo-lhes "status" de direitos fundamentais e aplicabilidade imediata. Entretanto, a doutrina vem questionando a real dimensão da aplicabilidade e eficácia dos direitos fundamentais dos trabalhadores no ordenamento jurídico brasileiro.

A perspectiva da doutrina alemã em relação à aplicabilidade dos direitos fundamentais laborais é tímida visto que a Constituição alemã preocupou-se em delinear um arcabouço geral de direitos fundamentais baseados nos direitos de primeira geração.

A opção da Constituição alemã em ser menos específica quanto aos direitos laborais permitiu construções doutrinárias como as de Ernst-Wolfgang Böckenförde e Ernst Forsthoff no sentido de que há de se analisar as hipóteses de aplicação

\footnotetext{
$\overline{77}$ ALEXY, Robert. op.cit., 1993, p.494.
} 
dos direitos fundamentais caso a caso pois, para serem aplicados, os direitos fundamentais necessitariam de graduação e diferenciação para cada caso particular.

Para esses autores alemães os direitos sociais não têm aplicabilidade imediata. Andreas Joachim Krell explica que a não inclusão de direitos sociais na lei Fundamental alemã não significa recusa ao ideário ligado a esses direitos, mas antevê o problema de sua efetivação. Denomina-se teoria da reserva do possível a mitigação da eficácia dos direitos sociais em razão da ideia de que estes somente podem ser efetivados se houver disponibilidade orçamentária do Estado para tanto.

Ao interpretar o artigo 12, inciso I, da lei Fundamental daquele país, o Supremo Tribunal da República Federal da Alemanha reconheceu um problema de estrutura dos direitos fundamentais sociais e delimitou o gozo dos direitos fundamentais sociais na medida em que fosse possível ao Estado garantir, em seu orçamento, a verba necessária para sua fruição.

A crítica que se faz é que a teoria da reserva do possível criada na Alemanha não pode ser aplicada no Brasil indiscriminadamente como meio de impedir a eficácia dos direitos fundamentais laborais. Isso porque, como explica Andreas Joachim Krell, a doutrina portuguesa utilizou-se das teorias do direito alemão e muitos doutrinadores brasileiros simplesmente transpuseram estas teorias (como reserva do possível e mínimo existencial) para o direito brasileiro. No mesmo sentido, Jorge Reis Novais, (faltou informação???) na obra "Direitos sociais: teoria jurídica dos direitos sociais enquanto direitos fundamentais"

Krell condena tal prática, dizendo que não condiz com os verdadeiros preceitos do direito comparado, e demonstra que a decisão do tribunal alemão que aplicou a teoria da reserva do possível a caso concreto não poderia simplesmente ser transposta para o Brasil, seja por se tratar de um país de realidade completamente distinta da Alemanha, ou por causa das diferenças nos sistemas jurídicos dos dois países, seja por causa da flagrante incompatibilidade na aplicação da teoria no Brasil com vistas a solucionar a questão da eficácia dos direitos fundamentais dos trabalhadores. Trata-se do que Maria Helena Diniz denomina "colonialismo jurídico": transportar institutos estrangeiros para o sistema jurídico brasileiro de maneira indistinta, sem preocupação com a realidade social do país.

No Brasil continua a existir a necessidade de concretização dos direitos fundamentais trabalhistas, visto que o simples enunciado de aplicabilidade imediata

${ }^{78}$ NOVAIS, Jorge Reis. Direitos sociais: teoria jurídica dos direitos socais enquanto direitos fundamentais. 2.ed. Lisboa: AAFDL, 2016. 
presente na Constituição não foi capaz de garantir a eficácia desses direitos. O Poder Legislativo permanece inerte, restando como solução última contar com o protagonismo do Poder Judiciário quando provocado a se manifestar sobre o tema.

\section{REFERÊNCIAS}

ABRAMOVICH, Victor; COURTIS, Christian. Apuntes sobre la exigibilidad judicial de los derechos sociales. In: SARLET, Ingo Wolfgang (Org.). Direitos fundamentais sociais: estudos de direito constitucional, internacional e comparado. Rio de Janeiro: Renovar, 2003.

ALEXY, Robert. Teoria de los derechos fundamentales. Madrid: Centro de Estúdios Constitucionales, 1993.

BALEEIRO, Aliomar. Constituições Brasileiras:1891. Brasília: Senado Federal e Ministério da Ciência e Tecnologia, Centro de Estudos Estratégicos, 1999.

BRASIL. Consolidação das Leis do Trabalho. 46. ed. São Paulo: LTr, 2016.

BARRETTO, Vicente Paulo. Reflexões sobre os direitos sociais. In: SARLET, Ingo Wolfgang (Org.). Direitos fundamentais sociais: estudos de direito constitucional, internacional e comparado. Rio de Janeiro: Renovar, 2003.

BOBBIO, Norberto. A era dos direitos. 8. ed. Rio de Janeiro: Campus, 1992.

BÖCKENFÖRDE, Ernst-Wolfgang. Staat, Verfassung, Demokratie: Studien zur Verfassungstheorie und zum Verfassungsrecht. Tradução de Günther Maluschke. 2. Aufl. Frankfurt am Main: Suhrkamp, 1992.

CANOTILHO, J.J. Gomes. Direito constitucional e teoria da Constituição. 7.ed. 18a reimpressão. Lisboa: Almedina, 2003.

CASTELO, Jorge Pinheiro. 0 direito material e processual do trabalho e a pósmodernidade: a CLT, o CDC e as repercussões do Novo Código Civil. São Paulo: LTr, 2003. 
DINIZ, Maria Helena. Norma constitucional e seus efeitos. São Paulo: Saraiva, 2001.

FERREIRA, Antonio Casimiro. Para uma concepção decente e democrática do trabalho e dos seus direitos: (re) pensar o direito das relações laborais. In: SANTOS, Boaventura de Souza (Org.). A globalização e as ciências sociais. 2. ed. São Paulo: Cortez, 2002.

FORSTHOFF, Ernst. Rechsstaat im Wandel: Verfassungsrechtliche Abhandlungen 1954-1973. Tradução de Günther Maluschke. 2. Auflage, Verlag C.H.Beck, Munchen, 1976.

FRENCH, John D. Afogados em leis: A CLT e a cultura política dos trabalhadores brasileiros. São Paulo: Perseu Abramo, 2001.

KRELL, Andreas Joachim. Direitos sociais e controle judicial no Brasil e na Alemanha: os (dês) caminhos de um direito constitucional "comparado". Porto Alegre: Sergio Antonio Fabris, 2002.

LIMA, Martônio Mont'Alverne Barreto. Voto secreto nos Legislativos Estaduais e Municipais, ou de como as coisas podem mudar. In: CAVALCANTE, Ronald Soares (Org.). Estudos de Direito Constitucional: homenagem a Paulo Bonavides. São Paulo: LTr, 2001.

MEIRELES, Edilton. Constituição do trabalho: o trabalho nas Constituições da Alemanha, Brasil, Espanha, França, Itália e Portugal. 2.ed. São Paulo: LTr, 2014.

MIRANDA, Jorge. Manual de Direito Constitucional. 6. ed. Coimbra: Coimbra Editora, 1997, t. I.

NOVAIS, Jorge Reis. Direitos sociais: teoria jurídica dos direitos socais enquanto direitos fundamentais. 2.ed. Lisboa: AAFDL, 2016.

PEREZ LUÑO, Antonio Enrique. Derechos humanos, Estado de Derecho y Constitución. 5. ed. Madri: Tecnos, 1995.

SARLET, Ingo Wolfgang. A eficácia dos direitos fundamentais: uma teoria geral dos direitos fundamentais na perspectiva constitucional. 10. ed. Porto Alegre: Livraria do Advogado, 2010. 
SILVA, José Afonso da. Aplicabilidade das normas constitucionais. 6. ed. São Paulo: Malheiros, 2003.

SILVA, José Afonso da. Curso de Direito Constitucional Positivo. 24. ed. Rio de Janeiro: Malheiros, 2004.

SILVA, Virgílio Afonso da. Direitos fundamentais: conteúdo essencial, restrições e eficácia. 2.ed., 4a tiragem. Rio de Janeiro, Malheiros, 2017.

TORRES, Ricardo Lobo. A metamorfose dos direitos sociais em mínimo existencial. In: SARLET, Ingo Wolfgang (Org.). Direitos fundamentais sociais: estudos de direito constitucional, internacional e comparado. Rio de Janeiro: Renovar, 2003.

Recebido em: 13 de fevereiro de 2017 Aceito em: 20 de junbo de 2017 